\title{
Peran Perbankan Syariah Dalam Implementasi Wakaf Uang Untuk Pengembangan Industri Halal Di Jawa Timur
}

\section{PERAN PERBANKAN SYARIAH DALAM IMPLEMENTASI WAKAF UANG UNTUK PENGEMBANGAN INDUSTRI HALAL DI JAWA TIMUR}

\author{
Dunyati Ilmiah *1 \\ Dosen Universitas Alma Ata \\ dunyatiilmy@almaata.ac.id
}

\begin{abstract}
One of the potentials of Islamic social finance needs to be optimized through waqf. Waqf has long been recognized by the Muslim community as a form of amal Jariyah which plays an important role in social, economic, and cultural development to improve social welfare. In addition to carrying out the function of collecting and distributing funds, the role of Islamic banking can also carry out social functions, because it is one of the Islamic financial institutions that can receive cash waqf and becomes a place for Nadzir to manage waqf funds. The development of the halal industry is currently a trend and is favored by many entrepreneurs. However, during the current pandemic, many UMKM have experienced a decline in turnover and even lost capital due to decreasing consumer purchasing power. Therefore, it is necessary to increase business using capital inflow without interest, namely through the role of Islamic banking in implementing cash waqf for the development of the halal industry.
\end{abstract}

Keywords: Islamic Banking, Money Waqf, Halal Industry, G21

\begin{abstract}
ABSTRAK
Potensi Islamic social finance perlu dioptimalkan salah satunya melalui wakaf. Wakaf telah lama dikenal masyarakat muslim sebagai salah satu bentuk amal jariyah yang berperan penting bagi pengembangan sosial, ekonomi dan budaya dalam rangka untuk meningkatkan kesejahteraan masyarakat. Peran perbankan syariah selain melaksanakan fungsi menghimpun dan menyalurkan dana juga dapat melakukan fungsi sosial, karena merupakan salah satu Lembaga Keuangan Syariah yang dapat melakukan penerimaan wakaf uang dan menjadi tempat pengelolaan dana wakaf oleh Nadzir. Pengembangan industri halal saat ini menjadi sebuah trend dan banyak digemari oleh usahawan. Namun di saat pandemi saat ini banyak UMKM yang mengalami penurunan omset bahkan kehilangan modal karena menurunnya daya beli konsumen. Oleh karena itu, perlu adanya peningkatan usaha dengan cara pemasukan modal tanpa bunga, yaitu melalui peran perbankan syariah mengimplementasi wakaf uang untuk pengembangan industri halal.
\end{abstract}

Kata kunci: Perbankan Syariah, Wakaf Uang, Industi Halal, G21 


\section{Dunyati Ilmiah.}

\section{A. PENDAHULUAN}

Pandemi corona membuat banyak orang terpukul secara ekonomi, wabah corona memaksa banyak orang diam di rumah. Pada sektor konsumsi rumah tangga terjadi ancaman kehilangan pendapatan dan tidak dapat memenuhi kebutuhan hidup terutama rumah tangga miskin dan pekerja informal. Perekonomian tidak stabil, angka kemiskinan dan pengangguran semakin meningkat. Menanggapi hal tersebut perlu adanya peran perbankan syariah sebagai Lembaga intermediasi dengan menyerap dana dari masyarakat untuk disalurkan kembali kepada masyarakat, salah satu caranya dengan mengimplementasikan wakaf, karena wakaf merupakan salah satu jaring pengaman sosial di tengah wabah corona.

Potensi Islamic social finance perlu dioptimalkan salah satunya melalui wakaf. Wakaf telah lama dikenal masyarakat muslim sebagai salah satu bentuk amal jariyah yang berperan penting bagi pengembangan sosial, ekonomi dan budaya dalam rangka untuk meningkatkan kesejahteraan masyarakat. Salah satu bentuk wakaf yang akhir-akhir ini mulai banyak diperkenalkan adalah wakaf uang. Wakaf uang sebagai salah satu alternatif atas pengentasan kemiskinan telah diterapkan di beberapa Negara Islam. Terutama di Bangladesh (Mannan, 2001).

Bank Syariah sebagai salah satu LKS (Lembaga Keuangan Syariah) PWU (Penerima Wakaf Uang) memiliki dasar hukum yaitu UU No. 21 tahun 2008 tentang Perbankan Syariah, dimana dijelaskan bahwa Bank Syariah adalah Bank 


\section{Peran Perbankan Syariah Dalam Implementasi Wakaf Uang Untuk Pengembangan Industri Halal Di Jawa Timur}

yang menjalankan kegiatan usahanya berdasarkan Prinsip Syariah dan menurut jenisnya terdiri atas Bank Umum Syariah dan Bank Pembiayaan Rakyat Syariah (pasal 1 angka 7). Disamping melaksanakan fungsi menghimpun dan menyalurkan dana masyarakat di atas, bank syariah juga dapat melakukan fungsi sosial berupa penerimaan dana zakat, infak, sedekah dan hibah, serta menyalurkannya kepada organisasi pengelola zakat (pasal 4 ayat 2). Selain itu, bank syariah dapat menghimpun wakaf uang dan meneruskannya kepada nazhir yang ditunjuk (pasal 4 ayat 3) (BWI, 2011).

Untuk melakukan penghimpun dana wakaf perlu adanya mobilisasi efektif dan empiris yang mudah dalam pelayanan dan administrasi atau dengan model dana abadi (Ilmiah, 2020). Saat ini ketertarikan masyarakat berwakaf uang merupakan potensi bagus untuk dimanfaatkan. Agar tercapainya kesejahteraan umat melalui wakaf uang tentu sangat berkaitan dengan penggelolaan dana wakaf oleh Nadzir melalui jaringan Lembaga Keuangan Syariah (LKS). Perbankan syariah merupakan salah satu LKS yang dapat melakukan penerimaan wakaf uang dan menjadi tempat pengelolaan dana wakaf oleh Nadzir. Perbankan syariah memiliki potensi besar dalam mengoptimalkan pengumpulan dan pengelolaan wakaf uang. Perbankan syariah dalam pengelolaan wakaf uang memiliki tanggung jawab besar untuk kelangsungan wakaf uang dan optimalisasi kesejahteraan umat. 


\section{Dunyati Ilmiah.}

Harta yang diwakafkan tidak akan habis, karena yang diambil hanya hasil dari pemanfaatannya. Wakaf memiliki peluang untuk dimanfaatkan dengan tujuan meningkatkan kesejahteraan. Wakaf sudah ada sejak Islam datang, wakaf telah terbukti menjadi instrument jaminan sosial untuk meningkatkan kesejahteraan hidup. Wakaf ada dua instrument yaitu wakaf uang yang sifatnya lebih fleksibel dan wakaf benda yang sifatnya harta tidak bergerak. Untuk menunjang dan mengembangkan kegiatan-kegiatan soial, ekonomi dan kebudayaan produktif maka wakaf uang bisa menjadi alternatif pilihan.

Indonesia telah lama terjerat dalam permasalahan ekonomi seperti pengangguran dan kemiskinan. Masalah ini sulit dihindari karena jumlah penduduk Indonesia yang dapat dibilang tidak sedikit, khususnya di area Jawa Timur yang berjumlah 37.476.011jiwa (Sumber: Badan Pusat Statistik 2015). Maka dari itu, untuk meminimalisir masalah tersebut diperlukan faktor pendorong yang dapat memicu perkembangan ekonomi. UKM (Usaha Kecil Menengah) adalah salah satu bentuk aktivitas yang terbukti membantu pertumbuhan ekonomi di Indonesia, khususnya daerah Jawa Timur. UKM sendiri merupakan bentuk usaha yang banyak diminati oleh masyarakat karena tidak membutuhkan modal besar seperti usaha-usaha lain pada umumnya. Oleh karena itu, banyak masyarakat yang tertarik untuk terjun dalam bisnis UKM. Perekonomian di Jawa Timur pun didominasi oleh keberadaan UKM. Dalam perkembangannya, UKM 


\section{Peran Perbankan Syariah Dalam Implementasi Wakaf Uang Untuk Pengembangan Industri Halal Di Jawa Timur}

juga ditunjang oleh adanya sumber daya alam yang heterogen serta lokasi Jawa Timur sebagai pasar strategis di pulau Jawa (Santoso, 2019).

Pengembangan industri halal saat ini menjadi sebuah trend dan banyak digemari oleh usahawan dan konsumen di Jawa Timur. Dari pihak pengusaha lebih memiliki rasa aman, damai dan dari pihak konsumen tidak khawatir lagi terkait kehalalan produk yang akan dibeli. Namun di saat pandemi saat ini banyak UMKM yang mengalami penurunan omset bahkan kehilangan modal karena menurunnya daya beli konsumen. Perlu adanya peningkatan usaha dengan cara pemasukan modal tanpa bunga. Di sinilah peran perbankan syariah perlu mengantisipasi untuk mengimplementasi wakaf uang dalam rangka pengembangan industri halal.

Posisi Indonesia sebagai pasar besar produk halal. Indonesia masuk TOP Expenditure di tiap Industri, namun tidak sebagai player.

\section{Tabel 1. Indonesia TOP Expenditure}

\begin{tabular}{|c|r|r|r|r|r|}
\hline Industry & 20 & 20 & Indone & Expen & Play \\
& 15 & 21 & sia & d. & er \\
& & & & Rank & Ran \\
& & & & & $\mathrm{k}$ \\
\hline Halal & 1,7 & 1,9 & 0,16 & 1 & - \\
\hline
\end{tabular}




\section{Dunyati Ilmiah.}

\begin{tabular}{|c|c|c|c|c|c|}
\hline $\begin{array}{l}\text { Islamic } \\
\text { Finance }\end{array}$ & $\begin{array}{l}2,0 \\
0\end{array}$ & $\begin{array}{l}3,4 \\
6\end{array}$ & 0,02 & 10 & 10 \\
\hline $\begin{array}{l}\text { Halal } \\
\text { Travel }\end{array}$ & $\begin{array}{l}0,1 \\
5\end{array}$ & $\begin{array}{l}0,2 \\
4\end{array}$ & 0,01 & 5 & - \\
\hline $\begin{array}{l}\text { Hala } \\
\text { Fashion }\end{array}$ & $\begin{array}{l}0,2 \\
4\end{array}$ & $\begin{array}{l}0,3 \\
7\end{array}$ & 0,01 & 5 & - \\
\hline $\begin{array}{l}\text { Halal } \\
\text { Media \& } \\
\text { Recreatio } \\
\text { nal }\end{array}$ & $\begin{array}{l}0,1 \\
9\end{array}$ & $\begin{array}{l}0,2 \\
6\end{array}$ & 0,01 & 6 & - \\
\hline $\begin{array}{l}\text { Halal } \\
\text { Pharmac } \\
\text { y \& } \\
\text { Cosmetic } \\
\text { s }\end{array}$ & $\begin{array}{l}3,8 \\
4\end{array}$ & $\begin{array}{l}6,3 \\
8\end{array}$ & 0,22 & - & - \\
\hline
\end{tabular}

Sumber: Bank Indonesia (Festival Ekonomi Syariah, Makassar 25 Agustus 2017)

Penelitian yang dilakukan oleh Abdullah Ubaid mengenai kemitraan nadzir dengan bank syariah dalam mengembangkan wakaf uang studi kasus di Indonesia, Bangladesh, dan Yordania menyatakan bahwa, instrument wakaf uang dalam institusi Bank Syariah yaitu di beberapa Negara, dalam mengembangkan wakaf uang, nazhir tidak hanya bekerja sendirian. Tetapi, ia melibatkan Bank 


\section{Peran Perbankan Syariah Dalam Implementasi Wakaf Uang Untuk Pengembangan Industri Halal Di Jawa Timur}

Syariah sebagai mitra strategis dalam pengelolaan wakaf uang. Agar wakaf uang tidak menjadi susut, maka nazhir menggandeng Bank Syariah sebagai mitra dalam pengelolaannya. Langkah ini telah dilakukan di beberapa negara: di antaranya adalah Indonesia, Bangladesh, dan Yordania. (Ubaid, 2014).

Dari hal tersebut permasalahan ekonomi saat ini adalah menurunnya pendapatan masyarakat dan menurunnya kegiatan UMKM. Oleh karena itu penelitian ini fokus pada peran perbankan syariah dalam implementasi wakaf uang untuk pengembangan industri halal di Jawa Timur.

\section{B. TINJAUAN PUSTAKA}

\section{Dasar Hukum Wakaf Uang}

Mengenai wakaf tunai atau wakaf uang, MUI telah membolehkan, ini dibuktikan dengan adanya fatwa MUI Indonesia tanggal 11 Mei 2002 yang berbunyi:

a. Wakaf uang (cash wakaf/ waqf al-nuqud) adalah wakaf yang dilakukan seseorang, kelompok orang, lembaga atau badan hukum dalam bentuk uang tunai.

b. Termasuk ke dalam pengertian uang adalah surat-surat berharga.

c. Waqaf uang hukumnya jawaz (boleh).

d. Wakaf uang hanya boleh disalurkan dan digunakan untuk hal-hal yang dibolehkan secara syar'i. Nilai pokok wakaf uang harus dijamin kelestariannya, tidak boleh dijual, dihibahkan dan atau diwariskan. 


\section{Dunyati Ilmiah.}

Berdasarkan UU wakaf, wakif adalah pihak yang mewakafkan harta benda miliknya yang dapat meliputi : perseorangan, organisasi, dan badan hukum. Sementara itu nazhir adalah pihak yang menerima harta benda wakaf dari wakif untuk dikelola dan dikembangkan sesuai dengan peruntukannya. Sementara pihak yang akan mengelola dan mengawasi benda wakaf dilakukan oleh nazhir. Berdasarkan Pasal 9 UU wakaf, nazhir dapat merupakan: perseorangan, organisasi, dan badan hukum.

Wakaf uang merupakan salah satu bentuk inovasi yang memungkinkan pengelolaan wakaf lebih fleksibel. Model wakaf memberikan kemungkinan partisipasi umat Islam secara lebih luas amal. Lebih fleksibel karena benda tersebut berupa benda yang dapat digerakkan dan juga bersifat simbolis memungkinkan investasi dan penggunaan yang lebih beragam. Oleh karena itu, tingkat partisipasi publik diharapkan menjadi lebih tinggi karena nominal wakaf tunai dapat dipecah menjadi pecahanpecahan kecil yang dapat diakses oleh semua orang. Hadirnya wakaf uang memungkinkan wakaf menjadi instrumen sedekah bagi semua orang. Pemberian uang tidak hanya untuk orang kaya tetapi juga untuk mereka yang tidak mampu secara ekonomi mapan (Farid, 2016).

\section{Peran Perbankan Syariah dalam Implementasi Wakaf Uang}

Peran LKS sangat strategis terutama dalam pengembangan wakaf uang di Indonesia. Peran strategis ini salah satunya terkait dengan status hukum lembaga ini karena ditunjuk langsung oleh Menteri Agama sebagai lembaga berwenang 


\section{Peran Perbankan Syariah Dalam Implementasi Wakaf Uang Untuk Pengembangan Industri Halal Di Jawa Timur}

dalam penerimaan wakaf uang. Hal ini disebutkan dalam UU No. 41 tahun 2004

Pasal 28 tentang wakaf yang berbunyi: 'Wakif dapat mewakafkan benda bergerak berupa uang melalui lembaga keuangan syariah yang ditunjuk oleh menteri'. Dalam kaitan ini menteri memiliki wewenang untuk menunjuk lembaga keuangan syariah tertentu yang memenuhi persyaratan atas saran dan pertimbangan dari Badan Wakaf Indonesia (Pasal 24 ayat 1 Penjelasan).

Undang-undang No. 41 tahun 2004 memberikan syarat-syarat tertentu bagi LKS yang dapat menerima dana wakaf uang masyarakat. Persyaratan persyaratan ini meliputi: (a). LKS harus menyampaikan permohonan secara tertulis kepada Menteri, (b). melampirkan anggaran dasar dan pengesahan sebagai badah hukum, (c). memiliki kantor operasional di wilayah Republik Indonesia, (d). bergerak di bidang keuangan syariah dan (e). memiliki fungsi titipan (wadi'ah). Persyaratan yang ketat ini dimaksudkan agar dana wakaf uang yang terkumpul di lembaga keuangan syariah ini dapat dijamin kelestarian dan keamanannya.

Lembaga Keuangan Syariah di Indonesia juga memiliki sumber daya manusia handal yang dapat menunjang tecapainya pengumpulan dana wakaf umat secara optimal. Selain itu, dana-dana yang terkumpul dalam lembaga keuangan syariah ini umumnya di bawah jaminan Lembaga Penjamin Simpanan sehingga dana wakaf uang yang terkumpul dapat terjamin keamanannya (Mulya E. Siregar, 2011: 49-59). 


\section{Dunyati Ilmiah.}

Dana wakaf uang yang terkumpul dapat dikelola atau diinvestasikan secara tidak langsung atau langsung nadzir ke berbagai sektor usaha yang halal dan produktif, melalui salah satu produk perbankan syariah yaitu investasi wakaf uang secara langsung melalui mudharabah muqayyadah. Dengan skema mudharabah muqayyadah, nadzir dapat menetapkan beberapa persyaratan atau kualifikasi tertentu terkait dengan pengelolaan dana wakaf uang. Bank syariah akan mencari mudharib atau proyek yang sesuai yaitu industri halal. Selanjutnya nadzir akan melakukan negosiasi dengan kesepakatan pada calon mudharib, termasuk dalam penetapan nisbah bagi hasil dan kewajiban pertanggungan proyek usaha. Berdasarkan kesepakatan, bank syariah selaku nadzir dapat menyalurkan dana wakaf uang ke dalam proyek yang telah disepakati sebagai satu bentuk investasi dana wakaf uang dan sudah dipilih secara langsung oleh nadzir (Cholil Nafis, 2009). Bagi hasil yang diperoleh dari proyek tersebut, akan dikurangi biaya operasional dan bagian nadzir, sebelum diteruskan kepada pihak-pihak yang telah ditetapkan sebagai penerima manfaat atas wakaf uang (mauquf alaih).

Implementasi wakaf uang bisa digunakan untuk membantu pada penanganan wabah corona melalui program kesehatan dan pangan yang didalamnya merupakan program konsumtif. Sementara untuk program produktif, wakaf uang bisa disalurkan untuk pengembangan industri halal yang 


\section{Peran Perbankan Syariah Dalam Implementasi Wakaf Uang Untuk Pengembangan Industri Halal Di Jawa Timur}

salah satu tujuannya untuk pengembangan UMKM dan mampu meningkatkan taraf hidup bagi pelaku industri halal.

Dengan mempopulerkan UMKM halal maka secara tidak langsung akan dapat memperkenalkan kepada masyarakat mengenai prinsip syariah. Harapanny adalah dapat meningkatkan indeks literasi dan indeks inklusi keuangan syariah bagi masyarakat Indonesia (Wardano, 2020).

\section{Industri Halal}

Halal merupakan karunia Allah SWT kepada manusia yaitu berupa rasa aman, sehat, bahagia. Halal bukan hanya sebatas label produk, halal merupakan kepercayaan, kehormatan, dan tanggung jawab (Abdalhamid Evans, 2018).

Indonesia memiliki potensi besar untuk mengembangkan industri halal karena besarnya permintaan dan kebutuhan, terutama untuk makanan, minuman dan kosmetik. Gubernur BI, Perry Warjiyo mengungkapkan tantangan perkembangan industri halal global dapat dimanfaatkan Indonesia, yaitu potensi pasar industri halal global yang semakin meningkat sejalan dengan populasi penduduk muslim sebanyak 1,84 miliar atau sekitar 24,4 persen dari populasi dunia. Saat ini potensi pengembangan sektor usaha berbasis syariah serta halal telah menjadi pilihan gaya hidup bagi muslim maupun non muslim (Perry Warjiyo, 2019).

Pengembangan industri halal akan menjadi lebih kompetitif dengan keterlibatan dari sektor industri keuangan dan perbankan syariah. Konsep 


\section{Dunyati Ilmiah.}

pengembangan industri untuk produk produk halal harus berjalan beriringan dengan perencanaan keuangannya. Dimulai dari aktivitas investasi, pelaku dalam industri halal harus memastikan bahwa usaha yang dilaksanakan sesuai dengan tuntunan syariah yang bebas dari unsur riba (bunga), maysir (ketidakpastian), dan gharar (perjudian) (Awang, 2016).

\section{METODOLOGI PENELITIAN}

Dalam penelitian ini menggunakan penelitian kualitatif bersifat deskriptif. Penelitian kualitatif adalah penelitian yang menghasilkan prosedur analisis yang tidak menggunakan analisis statistik atau penelitian yang didasarkan pada upaya membangun pandangan yang diteliti dengan rinci, dibentuk dengan kata-kata atau gambaran holistik (Moleong: 2006). Sedangkan, penelitian yang bersifat deskriptif merupakan penelitian yang dimaksudkan untuk memberikan data yang seteliti mungkin tentang peran perbankan syariah dalam implementasi wakaf uang untuk pengembangan industri halal di Jawa Timur.

Proses untuk mendapatkan data yang berkaitan dengan implementasi wakaf uang pada suatu objek pengembangan industri halal di Jawa Timur. Dengan menggunakan pendekatan kualitatif, peneliti melakukan analisis dengan cara mendeskripsikan, menggambarkan serta memberi arti hasil penelitian. Hasil pengamatan yang berkaitan dengan peran perbankan syariah dalam implementasi wakaf uang untuk pengemabangan industri halal di Jawa Timur 


\section{Peran Perbankan Syariah Dalam Implementasi Wakaf Uang Untuk Pengembangan Industri Halal Di Jawa Timur}

dianalisis dengan cara mendeskripsikan serta menguraikannya secara rinci sehingga mudah untuk dipahami.

Fokus kajian pada Bank Syariah sebagai Nazhir yaitu mendapat kewenangan penuh sebagai penerima, pengelola, dan penyalur dana wakaf. Wakif yang menyetorkan dana wakaf ke Bank Syariah dan akan menerima sertifikat wakaf yang diterbitkan Bank Syariah. Karena itu, tanggung jawab penggalangan, pengelolaan, dan distribusi hasil pengelolaan dana wakaf, sepenuhynya diserahkan pada Bank Syariah. Lalu difokuskan untuk pengembangan industri halal.

\section{HASIL DAN PEMBAHASAN}

\section{Peran Perbankan Syariah dalam Implementasi Wakaf Uang}

Berdasarkan Peran perbankan syariah dalam implementasi wakaf uang memiliki kewenangan penuh menjadi nazhir. Investor atau dalam hal ini disebut wakif menyetorkan dana wakaf ke perbankan syariah dan akan menerima sertifikat wakaf yang diterbitkan Bank Syariah. Semua tanggung jawab penggalangan, pengelolaan, penyalur dan distribusi hasil penggelolaan wakaf uang diserahkan kepada Bank Syariah.

Pengelolaan wakaf uang memang tidak mudah, karena dalam pengembangannya harus melalui berbagai usaha, dan usaha ini mempunyai resiko yang cukup tinggi. Oleh karena itu pengelolaan dan pengembangan wakaf 


\section{Dunyati Ilmiah.}

uang harus dilakukan oleh nazhir profesional. Tujuan dari pengelolaan dan pengembangan wakaf uang untuk kesejahteraan dan keadilan sosial.

Perbankan syariah ikut serta dalam menyalurkan pembiayaan pada sektor industri halal seperti halal travel, halal food, Islamic education, Islamic hospital, dan Islamic microfinance. Adapun skema yang ditawarkan bisa meliputi modal kerja maupun pembiayaan investasi untuk mendukung pertumbuhan bisnis dengan mekanisme yang dapat dipertanggungjawabkan dan menghasilkan barang dan jasa halal.

Skema Wakaf Uang di Perbankan Syariah

a. Bank syariah berperan sebagai LKS dan LKS-PWU menerima setoran/ pengumpulan dana wakaf uang

b. Sebagian dana disalurkan untuk program konsumtif dan program produktif

c. Pada program produktif bisa disalurkan pada pembiayaan usaha mikro, pengembangan UMKM, dan pembiayaan usaha.

d. Tata Kelola berdasarkan Wakaf Produktif untuk menjamin akuntabilitas penggelolaan dana wakaf uang. 


\section{Peran Perbankan Syariah Dalam Implementasi Wakaf Uang Untuk Pengembangan Industri Halal Di Jawa Timur}

\section{Bagan 1. Bentuk Skema Wakaf Uang di Perbankan Syariah}

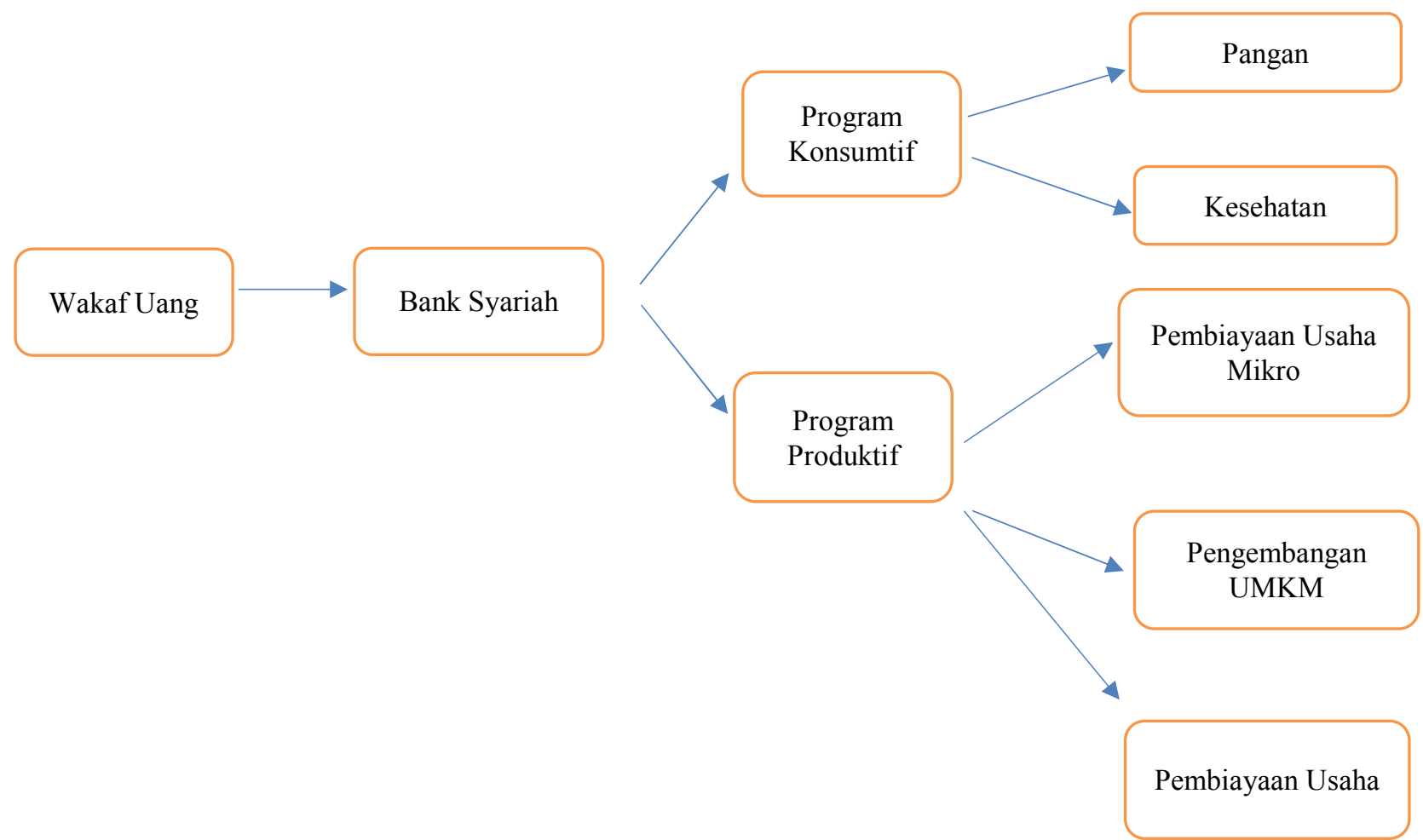

Pada peran perbankan syariah menyalurkan dana wakaf kepada dua program yaitu program konsumtif dan program konsumtif, tujuan dari program konsumtif yaitu pemanfaatan dana atas hasil wakaf uang yang telah diproduktifkan pada program produktif. Tujuan dari program konsumtfi yaitu mampu membantu dan meringankan masyarakat terkait pandemic yang saat ini masih belum usai, bisa berupa sembako, vitamin dan obat obatan. Pada program produktif perbankan menyalurkan ke beberapa bagian bisa melalui pembiayaan usaha mikro bagi usahawan yang mau merintis usaha, melalui pengembangan UMKM bagi pengusaha yang sudah memiliki usaha namun perlu adanya tambahan modal untuk mengembangakan usaha, terutama pada saat pandemic 


\section{Dunyati Ilmiah.}

sekarang banyak pengusaha mengeluhkan terkait usaha karena berkurangnya daya beli konsumen, sehingga perlu adanya inovasi maupun tambahan dana untuk memulihkan kondisi keuangan UMKM, dan pada program produktif yaitu pembiayaan usaha bisa disalurkan kepada pihak menengah ke atas untuk memperbesar usaha dengan akad-akad pembiayaan yang ada di perbankan syariah.

\section{Peran Bank Syariah dalam Pengembangan Industri Halal di Jawa Timur}

Pengembangan industri halal di Jawa Timur, perlu adanya peran aktif dari institusi keuangan, khususnya perbankan syariah. Peran perbankan syariah sangat berperan penting dalam halal integrity. Perbankan syariah mampu mengalokasikan sumber dana dari wakaf uang yang sudah dikelola dan sudah mendapatkan kepercayaan dari nasabah. Wakaf uang merupakan orientasi bisnis dan sosial yang ada dalam wakaf yaitu wakaf tunai yang diterima oleh nazir haruslah diinvestasikan untuk mencari profit sebesar besarnya untuk kemudian diberikan kepada mauquf alaih atau penerima manfaat wakaf.

Pengelolaan wakaf uang merupakan usaha-usaha yang dilakukan oleh pengelola dana wakaf uang (nazhir) dalam bentuk investasi usaha dengan mempertahankan nilai dana wakaf untuk memperoleh keuntungan. Untuk memutuskan investasi, sebelumnya dilakukan analisis proyek yang akan dibiayai. Syarat-syarat proyek yang dapat dibiayai oleh dana wakaf uang adalah sebagai berikut (Ubaid, 2015): 


\section{Peran Perbankan Syariah Dalam Implementasi Wakaf Uang Untuk Pengembangan Industri Halal Di Jawa Timur}

a. Usaha proyek dijalankan sesuai dengan syariah Islam

b. Kelayakan usaha disetujui oleh Komisi Investasi Nazhir

c. Tingkat kelayakan proyek harus memenuhi syarat:

1) Kelayakan proyek sesuai prinsip $5 \mathrm{C}$ (Character, Condition, Capital, Capacity, Collateral

2) Sumber pengembalian dapat dihitung berdasarkan studi kelayakan

3) Coverage of risk, apakah proyek diasuransikan atau tidak terkait potensi proyek gagal karena kesalahan atau bencana alam.

Peran perbankan syariah tidak hanya terbatas pada pembiayaan berbasis syariah yang bebas riba (bunga), maysir (ketidakpastian), dan gharar (perjudian), tapi juga pada seluruh tahapan proses produksi (halal value chain management) (Waharini, 2018).

Upaya dalam pengembangan industri halal dilakukan melalui tahap pendanaan, pendampingan, pengawasan. Dalam hal ini UMKM diberikan tambahan modal, setelah memperoleh tambahan modal, UMKM akan didampingi dalam menggunakan dana, promosi, dan pengalokasian yang tepat. Selanjutnya diberikan pengawasan dan pengarahan terkait kesesuaian prinsip prinsip syariah. Oleh karena itu perbankan syariah mampu menyalurkan dana sosial agar UMKM di Jawa Timur dapat berkembang secara baik yang berlandaskan prinsip syariah.

\section{E. KESIMPULAN DAN SARAN}

\section{Kesimpulan}




\section{Dunyati Ilmiah.}

Inti dari wakaf adalah pokok dari aset wakaf tidak boleh berkurang. Aset yang telah diserahkan oleh wakif (pemberi wakaf) kepada nazir (pengelola wakaf) haruslah benar benar dipelihara oleh nazir. Nazir bertanggung jawab untuk membesarkan aset tersebut. Nazir harus bertanggung jawab jika aset tersebut berkurang. Orientasi bisnis dan sosial yang ada dalam wakaf tunai yang dikelola oleh nazir harus diinvestasikan untuk mencari profit sebesar besarnya, kemudian diberikan kepada mauquf alaih (penerima manfaat) wakaf. Tujuan implementasi wakaf uang dalam mencari alternatif bisnis yaitu mampu menghasilkan laba agar banyak mauquf alaih yang bisa dibantu, salah satunya yaitu pengembangan industry halal pada UMKM di Jawa Timur.

\section{Saran}

Peran perbankan syariah sangat diperlukan bagi masyarakat, fungsi perbankan syariah bukan hanya menghimpun dan menyalurkan dana untuk tujuan investasi namun di dalam perbankan syariah adanya fungsi sosial untuk mensejahterahkan masyarakat. Maka dari itu perbankan bisa memperluas informasi kepada maasyarakat terkait literasi keuangan terutama wakaf uang.

\section{F. DAFTAR PUSTAKA}




\section{Peran Perbankan Syariah Dalam Implementasi Wakaf Uang Untuk Pengembangan Industri Halal Di Jawa Timur}

Abdullah Ubaid, Kemitraan Nazhir dengan Bank Syariah dalam Mengembangkan Wakaf Uang: Studi Kasus di Indonesia, Bangladesh, dan Yordania.

Awang, M. D., Noor, M. N., Muhammad , J., Abdullah, A., Rahman, S., \& Yahya, M. H. (2016). Acceptance and Application of Islamic Financial Planning among Small and Medium Enterprises Halal Operator in Peninsular of Malaysia. IJASOS- International E-Journal of Advances in Social Sciences, 2 (6).

Farid, D. (2016). The Waqf of Money as a Community Economic Empowerment Efforts. International Journal of Nusantara Islam, 4(2), 27-36.

H.M. Cholil Nafis, MA, "Wakaf Uang untuk Jaminan Sosial" dalam Al-Awqaf, Volume II, No.2, April 2009.

Ilmiah, D. (2020). Optimalisasi Asset Wakaf Melalui Sukuk Wakaf di Indonesia. JESI (Jurnal Ekonomi Syariah Indonesia), 9(2), 127-137.

Mannan, M. A. (2001). Sertifikat waqf tunai: sebuah inovasi instrumen keuangan Islam. PKTTI, UI. Mulya E. Siregar, Peranan Perbankan Syariah dalam Implementasi Wakaf Uang", dalam Al-Awaqaf, Volume IV, Nomor 04, Januari 2011.

Peraturan Pemerintah Nomor 42 tahun 2006 tentang Pelaksanaan UndangUndang Nomor 41 tahun 2004 tentang wakaf (Lembaran Negara Republik Indonesia Tahun 2006 Nomor 105; Tambahan Lembaran Negara Republik Indonesia Nomor 4667).

Santoso, D. N. (2019). Riview Pengaruh UKM Berbasis Inovasi Terhadap Perekonomian di Provinsi Jawa Timur.

Ubaid, A. (2014). Kemitraan Nazhir dengan bank syariah dalam mengembangkan wakaf uang: Studi kasus di Indonesia, Bangladesh, dan Yordania. Jurnal Al-Awqaf, 7(1), 47-56.

Ubaid, A. (2015). Kemitraan Nazhir dengan Bank Syariah dalam Mengembangkan Wakaf Uang: Studi Perbandingan di Indonesia, Bangladesh dan Yordania. KURIOSITAS: Media Komunikasi Sosial dan Keagamaan, 8(1), 15-24. 


\section{Dunyati Ilmiah.}

Wardani, N. L., \& Wahyu, A. M. (2020). Wakaf Uang Digital Untuk Milenial: Pamanfaatan Bonus Demografi Melalui Aplikasi Wakaf Uang Digital Untuk Mengembangkan Industri Halal. El-Aswaq, 1(1).

Waharini, F. M., \& Purwantini, A. H. (2018). Model Pengembangan Industri Halal Food di Indonesia. 